\title{
A Meta Analysis Study for Graduate Thesis on Media Literacy in Turkey
}

\section{Emel Arik ${ }^{{ }^{*}}$}

\author{
(D) 0000-0003-3748-7257
}

\author{
Muhammet Bilal Arik ${ }^{2}$ \\ (D) 0000-0002-4020-0555 \\ ${ }^{1}$ Akdeniz University, Antalya, TURKEY \\ ${ }^{2}$ Aydın Adnan Menderes University, Aydın, TURKEY \\ *Corresponding author: emelarik@akdeniz.edu.tr
}

Citation: Arik, E., \& Arik, M. B. (2021). A Meta Analysis Study for Graduate Thesis on Media Literacy in Turkey. Online Journal of Communication and Media Technologies, 11(4), e202121. https://doi.org/10.30935/ojcmt/11211

\section{ARTICLE INFO}

Received: 31 Aug 2020

Accepted: 29 Aug 2021

\section{ABSTRACT}

Media literacy includes the ability to access media messages in various contexts and formats, to be equipped to receive and detect these messages correctly and ultimately to produce new messages. It is a concept that gives the control power over the masses and makes border between the real world and the world created by the media. Media literacy has often been subject to scientific studies in higher education, especially in the fields of communication and education. This study aims to identify the general academic tendencies and approaches in the field of media literacy by examining the postgraduate theses written to the present day with the method of meta-analysis. It has been observed that the number of theses which have been written about this subject has been continuously increasing for about 13 years. In this article it is aimed to determine which research methods have been used in the theses written, what were the research focuses and their ideological orientations. In addition, the article contains current data about media literacy. This study, which analyzes all the theses written about media literacy until 2020, aims to contribute to the relevant literature by means of analyzing the nature of the postgraduate theses.

Keywords: media literacy, graduate thesis, meta analysis, educational sciences, communication sciences

\section{INTRODUCTION}

Media literacy outlines media texts by raising awareness of individuals, enabling them to be more resistant to potentially harmful effects, and invite media organizations to be more careful in a training program. As an educational program, it primarily aims to protect young people and children from the possible harmful effects of the media. Indeed, the relationship between media and children is often based on the assumption that children are open to influence and passive, especially given the effects of visual media on children. In this sense, media literacy is a reading method aimed at minimizing the harmful effects of the media (Kellner, 2001, p. 72).

This program provides a critical analysis opportunity for individuals, especially children and young people. It also makes the society know about the invisible / unseen face of the media by pointing to the difference between the real world and the world constructed through the media. While this transparency and openness allow the media-society relationship to develop on a healthier ground, it also enables the media to function more effectively as one of the most important institutions of democracy. Media literacy can be defined as the society's control of the media and directing their attention to the functioning mechanism of the media. Media literacy, which has been claimed to be a weapon by which people can defend themselves against the information they receive from the media, has been defined as the ability to reach texts in various contexts, to 
analyze and evaluate them and to create new messages. An advanced stage of media literacy is that audiences can annotate texts from their own contexts as well as produce their own media texts. The further targeted aim is to include the public in media production, which is clear that this diversification will have a democratizing function for the media environment (Buckingham, 2015, p. 132; Rogow, 2015, p. 27).

America, Canada, Australia, and England were the first emergence places of the Media Literacy Movement. To make media literacy more effective in various countries, research centers have been created, symposiums organized, and media literacy course has been adapted to the curriculum. It has been aimed that students not only become more conscious of media texts, but also take an active role in the creation process of media products. At this point, it has been seen that UNESCO (United Nations Educational, Scientific and Cultural Organization) also plays an active role in knowing and spreading that issue. UNESCO has been keeping media literacy on its agenda since the 1960s. After the meeting held by UNESCO with international experts from 19 countries in Germany in 1982, a statement was published to defend the necessity of media education. This statement emphasized that families, teachers, media workers, and decision-makers have a certain responsibility to improve criticism when using media texts (Buckingham, 1993, p. 34).

Since the 1980s, there have been many efforts in the world to expand the horizons of media literacy. As a result of these developments, educators have begun to agree on basic key concepts to be studied when media texts are used in the classroom. Afterwards, many meetings have been held on this subject. Especially in various meetings held in the United States of America communication scientists, critics, public health experts and academics have identified media exposure as a risk factor and suggested media literacy as a protective factor (Bostancl, 2007, p. 52).

As a result of the increasing media literacy debates in Western countries, media literacy courses have been included in the primary school curriculum in some countries (Bostancl, 2018, p. 22). Especially raising awareness of children against to the media has been one of the issues that some socially responsible states attach importance to. In Turkey, the studies related to media literacy in the Ministry of National Education and Radio and Television Supreme Council had been launched since 2005. Since 2007-2008 academic year all primary schools in our country these courses have been taught as elective courses in the 6th, 7th, and 8th grades.

In this article, the whole theses written about the graduate level media literacy in Turkey were examined by the meta-analysis method. Meta-analysis can be defined as the quantitative review and synthesis of related but independent study results. Although there is a large accumulation of literature on media literacy in our country, there is a lack of literature regarding the evaluation of the theses written. In this study, it is aimed to evaluate the theses written on media literacy from a holistic perspective and to be a pioneer for future studies. In this context, our main research problem is the orientation of the theses written in this field. While the research will also contribute to the literature, it is expected that it will present a new perspective on the current media literacy practices in our country. In this context, the study will seek answers to the following research questions:

- How and how often has the subject of media literacy been studied in the graduate thesis as a scientific research product in Turkey?

- What is the distribution of graduate thesis on media literacy in Turkey according to genre, language, year, institute, department, and universities?

- What is the distribution of graduate thesis on media literacy in Turkey according to subject, keyword, research method, data collection technique, and research subject?

- In which field and with what features has the concept of media literacy that is at the intersection of educational sciences and communication sciences been the subject of postgraduate theses?

- How often new communication technologies and new media literacy have been the subject of graduate thesis on media literacy in Turkey?

In this study, the National Thesis Center of the Council of Higher Education (http://tez2.yok.gov.tr/) database has been used. In this database, the concept of media literacy has been referenced and a total of 93 theses with media literacy have been identified. Therefore, the study has been limited to 93 theses (70 of them master, 23 of them doctorates) prepared between 2007-2020 years (Appendix). 


\section{Media Literacy: Conceptual Framework}

While mass media teach all kinds of behaviors, gender roles, values and news and information in general, they do not only produce visual / written images, sounds and discourse also sends subliminal messages against their background (Kellner, 2001). Today, the unique opportunities that technology provides to individuals have made media literacy education more important than ever (Valtonen et al., 2019). Media literacy is a skill that examines the information provided by the media with a critical point of view and seeks to deal with fake information conveyed by the media (Bulger \& Davidson, 2018, p. 24).

The important function of media literacy in democratic societies constitutes one of the requirements of ensuring participation, social justice and being a critical citizen. According to Joseph Turow, being a media literate requires the ability to apply critical thinking to mass media. It requires finding the meanings underneath the visible face of movies, ads, and other media content. The television shows you watch may require clear reasoning about the albums you listen to, magazines you read, and books you read. This means being a more aware and more responsible citizen, parent, voter, worker in our media society (Turow, 2003, p. 26).

James Potter says that ability to literate media gives individuals more control and more defense against the possible effects of the media. To be able to choose between different meanings contained in the media messages; to control the accuracy of information from different sources, media beliefs, attitudes, behaviors of individuals and social awareness of the impact on values has an extremely important contribution to the acquisition of skills of media literacy (Potter, 2013, p. 25). Potter claims that media literacy also allows people to avoid messages they don't need, while this ability is significant resistance to media manipulations (Potter, 2004, p. 10).

Some critics think that media literacy should be perceived as a philosophy and a critical way of thinking. According to Hobbs, media literacy is an umbrella with a broad spectrum of different educational philosophies, theories, frameworks, applications, environments, methods, goals, goals and results (Hobbs, 1998). Important theorists such as Hobbs (1998), Potter (2004, 2013), Buckhingham (1993, 2015), Aufderheide $(1989,1993)$ have drawn different routes to reach the desired results in media literacy and made various suggestions to reach effective results on subject.

Hobbs emphasized the necessity of answering 7 issues (protecting children, level of media production activity, relation with popular culture, ideological agenda, reaching more students, obtaining economic support from media organizations and tool to bring results) that are not compromised in media literacy (Hobbs, 1998). Buckhingham (1993) emphasizes the importance of knowing about the media industry and its production, media categories, media technologies, media languages, media audiences and media representation for effective media literacy. According to Buckingham (2015, p. 34), media literacy is a form of skill and competence; but it is also a critical way of thinking about cultural trends and tastes and includes traditional media and new media. Potter is more focused on expanding knowledge and perception, and knowing the compromises of producers of media texts, recognizing the media industry and has a comprehensive view of the impact of the media on society (Potter, 2013, p. 261).

Aufderheide lists the general principles of media literacy and the level of perception to be reached as follows: "All mass media are fictional. The media transmits the truth by editing. Not every message can be opened in the same way by the tracker. The media works commercially. Media texts transmit some values and ideologies. The media has some political and social aspects. In the media, form, and content are closely related to each other. Each media text is transmitted in an aesthetic form (Aufderheide, 1989, p. 27)." On the other hand, Ciurel emphasizes that to live in a world full of media, the audience must have a set of skills that enable them to cope with and process these messages or to look critically at the messages produced and distributed through new and traditional media channels (Ciurel, 2016). In summary, media literacy can be defined as knowledge, skills, and competencies to use and interpret media (French \& Richard, 2003, p. 18; Gu et al., 2019; Kamerer, 2013, p. 5).

\section{Media Literacy: Conceptual Framework}

Discussions about media literacy can protect children and young people from the negative effects of media have resonated in our country and necessary studies have been initiated at the academic level. Studies about 
this topic have increased in Turkey since the mid-2000s. Communication scientists working on the subject in the academic field have started to discuss the concept of media literacy on scientific platforms. The issue has been on the agenda of Radio and Television Supreme Council since 2005. For this purpose, Radio and Television Supreme Council has prepared a project and took action to teach the media literacy course as an elective course in the primary education program. Radio and Television Supreme Council specialists, who took the proposal to the Ministry of National Education received a positive response, and studies on literature about America and Europe within the framework of the agreement reached have been initiated. The program draft of the course was prepared together with communication academicians, concluding the studies and signing the protocol on the subject between Radio and Television Supreme Council and Ministry of National Education on 22 August 2006. In the 2006-2007 academic year, it was decided to start pilot practice in 5 primary schools. In 5 primary schools in 5 provinces, 780 seventh-grade students took media literacy courses. Within the scope of the media literacy course, the functions, purposes, importance of mass media, the meaning of media literacy, television broadcasting and program types, the effects of television, television watching habits, program analysis, smart signs, radio functions and effects, newspaper, magazine news, internet use information on the subjects has been given. The course has been taught as an elective course in the 6th, 7, and 8th grades in primary schools in Turkey since the 2007-2008 academic years (Bostanc1, 2007).

"Elementary Media Literacy Course Curriculum and Guide" was prepared by the Ministry of National Education and Radio and Television Supreme Council followed by "Elementary Media Literacy Course Teacher Handbook". It is aimed that the teachers who will give this course will have more detailed information about the subject. Curriculum and course materials have been updated and added in 2014 and 2018. Some existing disruptions have been tried to be eliminated. Media Literacy Association was established in 2017 and the same year the media literacy week began to be celebrated. One of the important milestones in media literacy that was a very popular topic especially in communication faculties was the Media Literacy Conference which held in Marmara University Faculty of Communication on 23-25 May 2005. (Türkoğlu, 2006).

The publication of the papers has made a significant contribution to the academic literature after the conference that included wide academician participation. After this conference, congresses and workshops on media literacy were organized in different universities, and it was aimed to keep the issue on the agenda at the academic level. In addition, while many copyrighted books written on the subject by communication academics have attracted attention since 2005, there are various articles published in academic journals in 2007 (Cansever, 2019; içen, 2020).

\section{METHODOLOGY}

In this study, which questioned the quantity and quality of graduate theses on media literacy in Turkey, the method of the meta-analysis was applied. Meta-analysis is a method of combining the results of multiple studies that are independent of each other on a particular subject and conducting statistical analysis of the obtained research findings. Meta-analysis studies aim to synthesize the results of the studies by collecting research on a particular subject. (Cohen \& Manion, 2001, p. 28).

Durlak (2015) has defined five basic steps that must be completed for meta-analysis. According to him; the research question should be presented clearly and precisely, the literature should be searched effectively, the descriptive information collected from each study should be correctly encoded, the coded numeric data should be analyzed statistically and finally the results should be interpreted. In this article Durlak's five basic steps have been considered as a model, first the literature was examined, after the conceptual framework, the basic codes related to the theses were created. After then these codes were analyzed and interpreted by converting them into numerical data.

\section{FINDINGS AND ANALYSIS}

93 theses were reached in the Thesis Center of the Presidency of the Council of Higher Education when the keyword "media literacy" was searched. 25\% (23) of these theses were written as doctoral thesis and $75 \%$ (70) as master thesis. 
Table 1. Distribution of Thesis by Genre and Languages

\begin{tabular}{lccc}
\hline Language & Master Thesis & PhD Thesis & Total \\
\hline English & 3 & 1 & 4 \\
Turkish & 67 & 22 & 89 \\
Total & 70 & 23 & 93 \\
\hline
\end{tabular}

Table 2. Distribution of Thesis by Years

\begin{tabular}{lccc}
\hline Publish Year & Master Thesis & PhD Thesis & Total \\
\hline 2020 & - & 1 & 1 \\
2019 & 15 & 1 & 16 \\
2018 & 6 & 5 & 11 \\
2017 & 6 & 2 & 8 \\
2016 & 4 & 2 & 6 \\
2015 & 7 & 2 & 9 \\
2014 & 5 & 2 & 7 \\
2013 & 5 & 1 & 6 \\
2012 & 5 & 2 & 7 \\
2011 & 5 & 2 & 7 \\
2010 & 4 & 2 & 6 \\
2009 & 4 & - & 4 \\
2008 & 3 & 1 & 4 \\
2007 & 1 & - & 1 \\
Total & 70 & 23 & 93 \\
\hline
\end{tabular}

Table 3. Distribution of Thesis by Institutes

\begin{tabular}{lccc}
\hline Institutes & Master Thesis & PhD Thesis & Total \\
\hline Social Science Institute & 56 & 11 & 67 \\
Educational Science Institute & 14 & 12 & 26 \\
Total & 70 & 23 & 93 \\
\hline
\end{tabular}

As shown in Table 1, the language of the theses are 95\% (89) Turkish and 5\% (4) English. 75\% of the theses are written in English (3) as master thesis while 25\% (1) is written as doctoral thesis. It was found that 89 of these theses are written in Turkish 75\% (67) for master's degree and 25\% (22) for doctoral thesis.

In Table 2, the publication year of the theses are shown in chronological order. Accordingly, the first thesis was written in 2007, titled "The effect of media literacy on the perception of messages in television series of secondary education 10th-grade students". This thesis was written at Çanakkale Onsekiz Mart University, Institute of Social Sciences, Department of Educational Sciences, Curriculum and Instruction. The first doctoral thesis was written in 2008 with the title of "The necessity of media and critical awareness as a tool of sovereign ideology: Media literacy", at Marmara University, Social Sciences. It was written in the field of journalism and communication sciences at the Institute, Department of Communication Sciences, General Journalism.

It is possible to say that the number of the studies in this research area has been steadily increasing for about 13 years. Only in 2013 and 2016, fewer theses were written than the previous year, and in other years the number of theses continued to increase compared to the previous year. Most thesis was produced in the year 2019. 16 theses written in the respective year constitutes 17\% of the thesis written in total.

All of the theses were prepared at the Institute of Social Sciences and the Institute of Educational Sciences. As can be understood from Table 3, the proportion of the theses written at the Institute of Social Sciences reaches $72 \%(67 \%)$, and this ratio was determined at the Institute of Educational Sciences as $28 \%$ (26\%). On the other hand, $84 \%$ (56) of the theses written at the Institute of Social Sciences is a master's degree and $16 \%$ (11) doctoral thesis, while 54\% (14) master's degree and 46\% (12) doctorate at the Institute of Educational Sciences thesis. Most of these the master's theses (80\%) were prepared at the Institute of Social Sciences and more than half of the doctoral thesis (52\%) were prepared at the Institute of Educational Sciences.

According to Table 3, a total of 93 theses were produced at the Institute of Social Sciences and Institute of Educational Sciences in 21 different departments as shown in Table 4. The department where the most thesis is written is Radio Television and Cinema (16) with $17 \%$ followed by Journalism (15) with $16 \%$ and Primary 
Table 4. Distribution of Thesis by Departments

\begin{tabular}{|c|c|c|c|}
\hline Department & Master Thesis & PhD Thesis & Total \\
\hline Radio Television Cinema & 15 & 1 & 16 \\
\hline Journalism & 12 & 3 & 15 \\
\hline Primary School & 13 & 2 & 15 \\
\hline Communication Science & 6 & 3 & 9 \\
\hline Educational Science & 3 & 4 & 7 \\
\hline Social Knowledge and Turkish Education & 4 & 3 & 7 \\
\hline Turkish Education & 2 & 2 & 4 \\
\hline Public Relation & 2 & 1 & 3 \\
\hline Media and Publishing & 1 & 1 & 2 \\
\hline Primary Science & 1 & 1 & 2 \\
\hline Computer \& Educational Science Edu. & 2 & - & 2 \\
\hline Educational Programme \& Education & 2 & - & 2 \\
\hline Pre-School Education & - & 1 & 1 \\
\hline English Teaching Education & 1 & - & 1 \\
\hline Social Knowledge Teaching Education & - & 1 & 1 \\
\hline Information \& Document Management & 1 & - & 1 \\
\hline Media \& Communication Systems & 1 & - & 1 \\
\hline Media \& Cultural Studies & 1 & - & 1 \\
\hline New Media & 1 & - & 1 \\
\hline Public Administration & 1 & - & 1 \\
\hline Fine Arts Education & 1 & - & 1 \\
\hline Total & 70 & 23 & 93 \\
\hline
\end{tabular}

Education (15). These three major disciplines have produced most the thesis by composing about half (49\%) of the theses written in total.

It was found that 93 theses written on media literacy were implemented in 34 different universities. Table $\mathbf{5}$ shows the distribution of theses by universities. "Other", Balikesir University (State), Galatasaray University (State), Maltepe University (Foundation), Ankara University (State), Adıyaman University (State), Istanbul Culture University of Commerce (Foundation), Istanbul University of Commerce (Foundation), Kadir Has University (Foundation), Sıtkı Koçman University (State), Niğde University (State), METU (State), Pamukkale University (State), Recep Tayyip Erdoğan University (State), Süleyman Demirel University (State), Üsküdar University (Foundation), Yaşar University (Foundation), Yüzüncü Yıl University (State) are the universities where this subject area has been researched. 17 theses has been prepared in 17 universities, 7 of which are foundations and 10 states. According to Table 5, in terms of ranking Gazi University (12) leads the chart, followed by Atatürk University (10), Marmara University (8), and Erciyes University (6) respectively. At the master's level, it is observed that the most of these studies took place at Atatürk University (9), while most of the thesis was produced at the Ph.D. level at Gazi University. At Gazi University, 58\% of the theses are doctoral and $42 \%$ are master's thesis. 
Online Journal of Communication and Media Technologies, 2021

Table 5. Distribution of Thesis by Universities

\begin{tabular}{|c|c|c|c|c|c|c|}
\hline \multirow{2}{*}{ University Name } & \multirow{2}{*}{ Kind } & \multicolumn{2}{|c|}{ Social Science Institute } & \multicolumn{2}{|c|}{ Educational Science Inst. } & \multirow{2}{*}{ Total } \\
\hline & & MA & PhD & MA & $\mathrm{PhD}$ & \\
\hline Gazi University & Public & 5 & 2 & - & 5 & 12 \\
\hline Atatürk University & Public & 6 & - & 3 & 1 & 10 \\
\hline Marmara University & Public & 5 & 1 & 1 & 1 & 8 \\
\hline Erciyes University & Public & 3 & 2 & 1 & - & 6 \\
\hline Anadolu University & Public & 2 & 1 & 1 & 1 & 5 \\
\hline 18 Mart University & Public & 2 & - & 1 & 2 & 5 \\
\hline Kocaeli University & Public & 4 & - & - & - & 4 \\
\hline Dumlupınar University & Public & 1 & - & - & 2 & 3 \\
\hline Ege University & Public & 2 & - & 1 & - & 3 \\
\hline Abant İzzet Baysal Ünv. & Public & 1 & 1 & 1 & - & 3 \\
\hline İstanbul University & Public & 2 & 1 & - & - & 3 \\
\hline 19 Mayıs Ünv. & Public & 2 & - & 1 & - & 3 \\
\hline Selçuk University & Public & 3 & - & - & - & 3 \\
\hline Fırat University & Public & 2 & - & - & - & 2 \\
\hline Akdeniz University & Public & 1 & 1 & - & - & 2 \\
\hline Giresun University & Public & 2 & - & - & - & 2 \\
\hline Hacettepe University & Public & 2 & - & - & - & 2 \\
\hline Other & Mixed & 11 & 2 & 4 & - & 17 \\
\hline Total & 34 & 56 & 11 & 14 & 12 & 93 \\
\hline
\end{tabular}

Table 6. Distribution of Thesis by Subjects

\begin{tabular}{|c|c|c|c|c|c|}
\hline \multirow{2}{*}{ Subjects } & \multicolumn{2}{|c|}{ Social Science Institute } & \multicolumn{2}{|c|}{ Educational Science Inst. } & \multirow[b]{2}{*}{ Total } \\
\hline & MA & $\mathrm{PhD}$ & MA & PhD & \\
\hline Education & 12 & 2 & 12 & 11 & 37 \\
\hline Communication Sciences & 11 & 2 & 1 & - & 14 \\
\hline Communication Sciences-Education & 3 & 3 & 1 & 1 & 8 \\
\hline Journalism & 6 & - & - & - & 6 \\
\hline Communication Sciences-Radio-Television & 5 & - & - & - & 5 \\
\hline Comm. Sciences-Journalism-Radio -Television & 5 & - & - & - & 5 \\
\hline Communication Sciences-Journalism & 2 & 2 & - & - & 4 \\
\hline Education and Instruction-Journalism & 2 & 1 & - & - & 3 \\
\hline Education and Instruction-Radio-Television & 2 & - & - & - & 2 \\
\hline Comm. Sciences-Public Administration & 2 & - & - & - & 2 \\
\hline CommunicationSciences-Public Relations & 1 & - & - & - & 1 \\
\hline Journalism-Public Relations & - & 1 & - & - & 1 \\
\hline Education and Teaching-Fine Arts & 1 & - & - & - & 1 \\
\hline Edu. and Instruction-Hit-Comm. Sciences & 1 & - & - & - & 1 \\
\hline Information and Document Management & 1 & - & - & - & 1 \\
\hline Turkish Language and Literature & 1 & - & - & - & 1 \\
\hline Education & 1 & - & - & - & 1 \\
\hline Total & 56 & 11 & 14 & 12 & 93 \\
\hline
\end{tabular}

The number, author, year, thesis name, type and subject of each thesis registered in the Thesis Center of the Presidency of Higher Education Council are indicated in Table 6. Education and Education, Communication Sciences, Journalism, Fine Arts, Public Relations, Radio and Television, Turkish Language and Literature are the departments where the theses have been created according to the topics specified in the thesis of Higher Education, Communication Sciences, Journalism, Fine Arts, Public Relations, Radio and Television, 9 separate topics such as Information and Document Management and Public Administration have been identified. Each of these topics is used at least once, but in some theses, more than one topic is mentioned. Accordingly, as seen in Table 6, 40\% (37) of 93 thesis includes Education and Teaching, followed by the subject of Communication Sciences by $15 \%$ (14).

Of 93 these theses were written on media literacy and for $90 \%$ (84) keyword information was reached, and for $10 \%$ (9) it was not achieved. At least 2, a maximum of 10, and 328 keywords were used in the accessible theses. Listing keywords that are most used in Table 7, as well as pointing to the field, the method could not list keywords with sample information. Some keywords that cannot be shown in Table 7 include Turkey, United States of America, Canada, Ethiopia, Afghanistan, Tunceli, Elazığ, Azerbaijan, New Zealand, Radio and 
Table 7. Distribution of Thesis According to Keywords

\begin{tabular}{|c|c|c|c|c|c|}
\hline Line & Keywords & Freq. & Line & Keywords & Freq. \\
\hline 1. & Media Literacy & 66 & 21. & Critical Pedagogy & 3 \\
\hline 2. & Media & 30 & 22. & Critical Approach & 3 \\
\hline 3. & Media Literacy Education & 13 & 23. & Communication & 3 \\
\hline 4. & Media Education & 10 & 24. & Adult Media Literacy & 3 \\
\hline 5. & Literacy & 9 & 25. & Children & 3 \\
\hline 6. & Mass Media Training & 8 & 26. & Television & 3 \\
\hline 7. & Program & 7 & 27. & Attitudes/Student Attitudes & 3 \\
\hline 8 & New Media & 7 & 28. & Curriculum/Material & 3 \\
\hline 9. & Social Media & 6 & 29. & Media Literacy Course & 3 \\
\hline 10. & New Media Literacy & 5 & 30. & Curriculum & 2 \\
\hline 11. & Media Literacy Skills & 5 & 31. & Critical Media Literacy & 2 \\
\hline 12. & Social Studies & 5 & 32. & Criticism & 2 \\
\hline 13. & Teacher, Teacher Opinions & 5 & 33. & Awareness/Critical Awareness & 2 \\
\hline 14. & Preschool Education/Teacher & 4 & 34. & Teacher Education & 2 \\
\hline 15. & Primary School/Primary School Students & 4 & 35. & Pedagogy & 2 \\
\hline 16. & Secondary School/ Secondary Education & 4 & 36. & Internet & 1 \\
\hline 17. & Turkish Teaching & 4 & 37. & Digital Media & 1 \\
\hline 18. & Teacher Candidates & 4 & 38. & Digital Technologies & 1 \\
\hline 19. & Critical Thinking & 4 & 39. & Social Media Literacy & 1 \\
\hline 20. & New Communication Technologies & 4 & 40. & Internet Media Literacy & 1 \\
\hline
\end{tabular}

Table 8. Distribution of Thesis According to Research Methods

\begin{tabular}{lccc}
\hline Method & Master Thesis & PhD Thesis & Total \\
\hline Quantitative & 36 & 3 & 39 \\
Qualitative & 23 & 12 & 35 \\
Qualitative and Quantitative & 11 & 8 & 19 \\
Total & 70 & 23 & 93
\end{tabular}

Television Supreme Council, Ministry of Education, semiotics, content analysis, analysis, perception, consciousness, can be exemplified as a citizen, citizen, etc. Accordingly, as stated in Table 7, the most commonly used keyword is media literacy compared to $20 \%$ (66), while it is media literacy (30), media literacy education (13), media education (10) is key follow the words. The lack of concepts such as the internet, digital media, digital technologies, which have an important place in today's media literacy education is also a remarkable element that is reflected.

According to Table 8, where research methods of theses are expressed, the method of quantitative research in $42 \%$ (39) of 93 theses reached, the qualitative research method in 38\% (35), and in 20\% (19) mixed, i.e., both qualitative and quantitative research methods were used together. The quantitative research method is determined to be preferred more often, while Table 9 reveals the preferred data collection tools in these researches.

Quantitative research method is used in $42 \%$ of the theses on media literacy, which is reflected in Table 9 as a frequently applied quantitative research data collection technique in the survey. Accordingly, survey is the most preferred technique with a ratio of $26 \%$ (24) and it was found that it is mostly used in the master theses. On the other hand, it is concluded that while one single data collection technique was used in some theses, several data collection techniques were used in some others. In this case, a second data collection technique such as survey-scale (5), questionnaire (5), questionnaire interview (5), questionnaire review (2) is used as well as theses using only questionnaire (24) were used in 93 theses, which means 39\% (36). 
Table 9. Distribution of Thesis Based on Data Collection Techniques

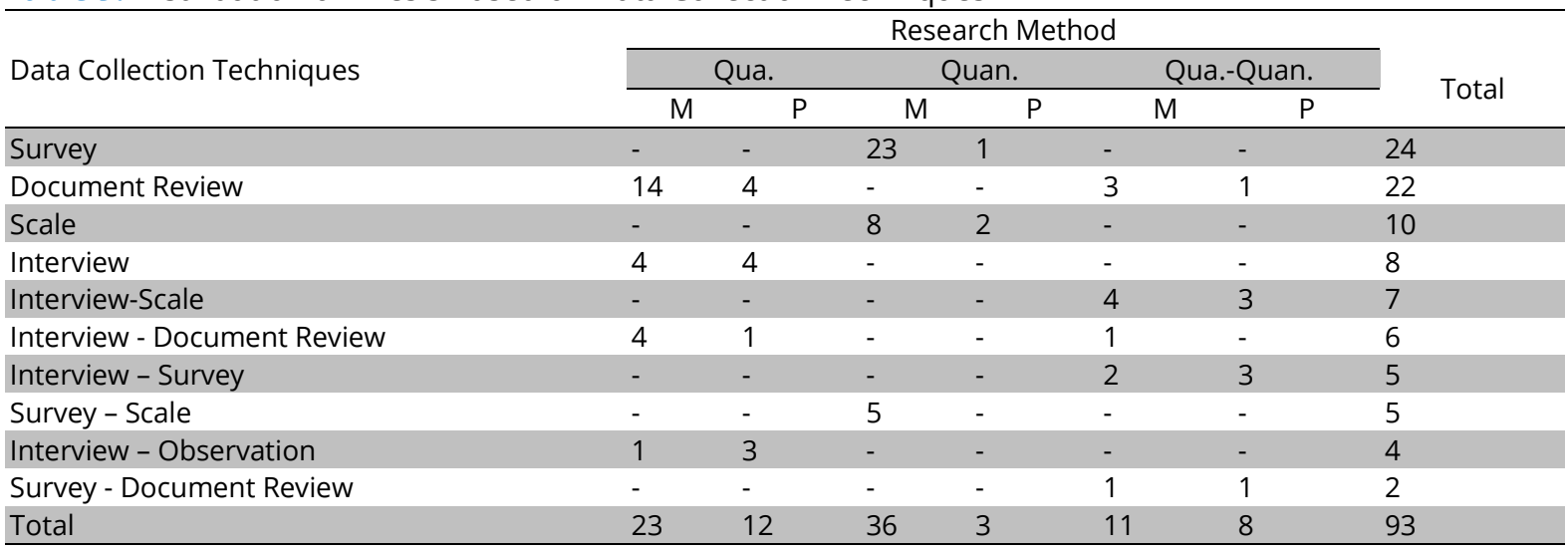

Table 10. Distribution of Theses According to Research Subject

\begin{tabular}{lccccccc}
\hline \multirow{2}{*}{ Research Subject } & \multicolumn{7}{c}{ Research Method } \\
\cline { 2 - 7 } & \multicolumn{3}{c}{ Qua. } & \multicolumn{2}{c}{ Quan. } & Qua. - Quan. & Total \\
\cline { 2 - 7 } Students & $\mathrm{M}$ & $\mathrm{P}$ & $\mathrm{M}$ & $\mathrm{P}$ & $\mathrm{M}$ & $\mathrm{P}$ & \\
Applications in Different Countries & 2 & 3 & 24 & - & 3 & 2 & 34 \\
Teacher Candidates & 9 & 2 & 1 & - & - & 1 & 13 \\
Teachers & - & 1 & 6 & 2 & - & 2 & 11 \\
Students - Teachers & 2 & 1 & 2 & - & 1 & 1 & 7 \\
Teaching Materials & - & - & - & 1 & 3 & 1 & 5 \\
Specialists in the field & 1 & 1 & - & - & 2 & - & 4 \\
New Media Texts & - & 1 & 1 & - & 1 & - & 3 \\
Literature & 2 & - & - & - & 1 & - & 3 \\
Media Texts & 2 & 1 & - & - & - & - & 3 \\
Students-Teachers-Parents & 3 & - & - & - & - & - & 3 \\
Study Curriculum & 1 & 1 & - & 1 & - & - & 3 \\
Literature & - & - & 2 & - & - & - & 2 \\
Instructional Materials and Program & 1 & - & - & - & - & - & 1 \\
Total & - & 1 & - & - & - & - & 1 \\
\hline
\end{tabular}

The second most commonly used technique after the survey is document review technique, literature review that can provide data in qualitative and quantitative research. While document review technique was used in $24 \%$ (22) of the theses, only, multiple data collection techniques such as interview-document review (6), survey-document review (2) was used, document review was determined in 32\% (30) of 93 theses.

Moreover, interview as data collection technique was frequently preferred and only interview (8), interview-scale (7), interview-document review (6), interview-questionnaire (5), interview-observation (4) techniques were used in 32\% (30) of the theses.

Table 10 shows the distribution of theses according to the research subject and points at research subject study groups and sampling knowledge. Accordingly, the focus of researches is of secondary school students with a $37 \%$ (34) ratio, and the intensity of studies aimed at the efficiency of the media literacy course is pointed out. Applications in different countries as research subjects at a rate of $14 \%$ (13) is observed and, European Countries, United States of America, Pakistan, Ethiopia, Canada, Norway, Germany, New Zealand, England, Ireland, Finland, France, and Austria samples are subjected to media literacy practices. The third frequently used research subject is university students who are studying in Social Studies Teaching Department of Education Faculties and who are candidates for the Media Literacy course in secondary education. The proportion of theses that investigate proficiency levels of candidate teachers was 12\% (11).

According to the information, which is not reflected in the table, 92\% (86) of the 93 theses investigating media literacy used mainstream and the remaining $8 \%(7)$ had critical perspective. On the other hand, a new model for the education of media literacy is available in a total of 8 theses, in other words, $9 \%$ of all theses composed of 1 master's degree and 7 Ph.D. degree. 


\section{CONCLUSION}

Media literacy aims at understanding whether media is effective in society and is a source in understanding culture and internalizing mechanisms of mass communication. Media messages also aims at developing strategies for analysis and discussion and increasing ability to interpret and perception of the individual about media content. In modern societies, it is vital to know the background of the media and its procedures by all the members of society. Graduate thesis on such an important subject and the analysis of these theses are also important to understand how the subject is addressed and what parameters are evaluated. For this purpose, the theses written on media literacy were evaluated by means of meta-analysis method and the results were reached in the context of research questions.

93 theses were reached as a result of the search made via the keyword "media literacy" in the Thesis Center of the Presidency of the Council of Higher Education. 25\% (23) of these theses were determined as Ph.D. and $75 \%$ (70) master thesis. The language of the theses written in Turkish is $95 \%$ (89) and 5\% (4) in English. Since the first, after the initial theses on media literacy, they have steadily increased in the following 13 years. Written in 2007, "Effects of media literacy on the perception of messages in television series on 10th-grade students" is the first thesis written in Turkey in this field. All the theses were prepared at the Institute of Social Sciences and the Institute of Educational Sciences. The proportion of theses written in the Institute of Social Sciences reaches $72 \%$ (67) while in the Institute of Educational Sciences is $28 \%(26 \%)$. Such theses are mostly written in Radio Television Cinema Departments which is $17 \%(16)$, then in Journalism and Primary Education Departments with a ratio of $16 \%$ (15). Institutes in which the departments are affiliated vary from one university to another. For example, Social Studies Education Department is in the Institute of Educational Sciences in some universities, and in the Institute of Social Sciences in some others. It was found that 93 theses written on media literacy were implemented in 34 universities. With a total of 12 dissertations, Gazi University is the university with the most thesis written in this field.

The most common keywords in those theses is in media literacy with a ratio of $20 \%$ (66), then media (30), and then media literacy training (13) and media education (10). Lack of concepts such as the Internet, digital media, digital technologies, which have an important place in today's media literacy education, is also observed. Qualitative research method was used in $42 \%$ (39) of the theses, qualitative research method in $38 \%$ (35), and $20 \%$ (19) is mixed. In other words, both qualitative and quantitative research methods were used. Survey is mostly used in quantitative research techniques. The second most commonly used technique after the survey is literature review, document review technique that can provide data in qualitative and quantitative research. The focus of the research is that $37 \%$ (34) is secondary school students, and the intensity of studies aimed at the efficiency of the media literacy course is pointed out. The applications in different countries with a rate of $14 \%(13)$ is observed as a research subject. The third frequently used research subject is university students who are studying in Social Studies Teaching Department of Education Faculties and who are candidates for Media Literacy in secondary education. Proportion of theses investigating proficiency levels of candidate teachers was $12 \%(11)$.

Although Communication Faculties often bring up the agenda of communication graduates to give media literacy course, there is no scientific research investigating competence of communication students in this field. Finally, 92\% (86) of the 93 theses on media literacy use mainstream perspective and the remaining $8 \%$ (7) critical a perspective. On the other hand, a new model for the education of media literacy is available in a total of 8 theses, 1 master's degree and 7 Ph.D. which equals $9 \%$ of all theses.

It is observed that theses written on media literacy offers an accumulation of literature with an increasing number in time, which is a contribution to scientific research and current practices, but it is also determined that repetition is perceived. It is concluded that the theses, allowing discussion in different dimensions of the subject, reflect a continuously evolving field, but do not reach a sufficient level of current information with the latest dimensions.

In summary, media literacy is a popular topic in both communication and educational sciences. Increase in the number of theses in this field will contribute to keep the subject on the agenda. It is hoped that these studies and their results will contribute to the media literacy policies of our country. This article has examined such theses by means of meta-analysis method. Content and discourse analysis of the graduate theses will 
provide a deeper examination of the academic studies. It is important to maintain such an important subject on the academic agenda for the development of communication science and to build new academic studies on the foundations of the past. Thus, this article was written to contribute to this ideal and it tries to inspire new researchers with its obtained results.

Author contributions: All authors were involved in concept, design, collection of data, interpretation, writing, and critically revising the article. All authors approve final version of the article.

Funding: The authors received no financial support for the research and/or authorship of this article.

Declaration of interest: Authors declare no competing interest.

Data availability: Data generated or analysed during this study are available from the authors on request.

\section{REFERENCES}

Arslan-Cansever, B. (2019). Investigation of third grade students' views on media literacy. International Journal of Educational Methodology, 5(2), 265-273. https://doi.org/10.12973/ijem.5.1.265

Aufderheide, P. (1989). Media literacy: resource guide. Ministry of Education.

Aufderheide, P. (1993). National leadership conference on media literacy. Conference report. Aspen Institute.

Bostancı, N. (2007). ilköğretim medya okuryazarlığı dersi öğretmen kitabı [Primary school media literacy lesson teacher's book]. Ministry of National Education Publishing.

Bostancı, N. (2018) ilköğretim medya okuryazarlığı dersi öğretim programı ve kılavuzu [Primary education media literacy course curriculum and guide]. Ministry of National Education Publishing.

Buckingam, D. (2009). Media education literacy learning and contemporary culture. Polity Press.

Buckingham, D. (1993). Children Talking Television: The making of television literacy. The Falmer Press.

Buckingham, D. (2015). The future of media literacy in the digital age: some challenges for policy and practice, Medienimpulse, Ausgabe, 47(2), 1-18. https://doi.org/10.21243/mi-02-09-13

Bulger, M., \& Davison, P. (2018). The promises, challenges, and futures of media literacy. Journal of Media Literacy Education, 10(1), 1-21. https://doi.org/10.23860/JMLE-2018-10-1-1

Ciurel, D. (2016). Media literacy: concepts, approaches and competencies. Professional Communication and Translation Studies, 8(9), 13-20.

Cohen, L., \& Manion, L (2001). Research methods in education. Routledge Falmer. https://doi.org/10.4324/9780203224342

Durlak, J. A. (1995). Understanding meta-analysis. In L. G. Grimm, \& P. R. Yarnold (Eds.), Reading and understanding multivariate statistics, American Psychological Association.

French, D., \& Richard, M. (2003). Media education across Europe. Taylor \& Francis e-Library. https://doi.org/10.4324/9780203204801

Gaines, E. (2010). Media literacy and semiotics. Palgrave Macmillan. https://doi.org/10.1057/9780230115514

Gu, X., Wang, C., \& Lin (2019). Examining scientific literacy through new media. EURASIA Journal of Mathematics, Science and Technology Education, 15(12), 1-14. https://doi.org/10.29333/ejmste/109948

Hobbs, R. (1998). The seven great debates in the media literacy movement. Journal of Communication, 48(1), 16-32, https://doi.org/10.1111/j.1460-2466.1998.tb02734.x

İçen, M. (2020). Developing media literacy through activities. International Journal of Educational Methodology, 6(3), 631-642. https://doi.org/10.12973/ijem.6.3.631

Kamerer, D. (2013). Media literacy, communication research trends. Routledge Falmer.

Kellner, D. (2001). New Technologies/New Literacies: Reconstructing education for the new millennium, International Journal of Technology and Design Education 11(1), 67-81. https://doi.org/10.1023/A:1011270402858

Potter, J. W. (2013). Media literacy. Sage Publications.

Potter, W. J (2004). Theory of media literacy, a cognitive approach. Sage Publications. https://doi.org/10.4135/9781483328881

Rogow, F. (2015). Media literacy in early childhood education: inquiry-based technology integration. In C. Donohue (Ed.), Technology and digital media in the early years: Tools for teaching and learning. Routledge.

Turow, J. (2003). Media today. Houghten Mifflin Company.

Türkoğlu, N. (Ed.) (2006). I. Uluslararası Medya Okuryazarlığı Konferansı bildiri kitabı [Proceedings of the I. International Media Literacy Conference]. Marmara University Faculty of Communication Publishing. 
Valtonen, T., Tedre, M., \& Vartiainen, H. (2019). Media literacy education in the age of machine learning. Journal of Media Literacy Education, 11(2), 20-36. https://doi.org/10.23860/JMLE-2019-11-2-2

\section{APPENDIX}

\section{Theses on Media Literacy in Turkey between 2007-2020}

\section{Unpublished doctoral dissertation}

1. Çelik, M. (2008). Media as a tool of dominant ideology and the need for critical awareness: Media literacy [Unpublished doctoral dissertation, Marmara University, Institute of Social Sciences].

2. Altun, A. (2010). Teaching of media literacy and its integration into social studies curricula [Unpublished doctoral dissertation, Gazi University, Institute of Education Sciences].

3. Çakmak, E. (2010). Comperative examination of primary media literacy curriculums and implementations of England and Turkey [Unpublished doctoral dissertation, Abant Izzet Baysal University, Institute of Social Sciences].

4. Sezen, D. (2011). New media literacies for a participatory culture: USA and Turkey [Unpublished doctoral dissertation, i̇stanbul University, Institute of Social Sciences].

5. Bilici, i. E. (2011). Proposal of a model for media literacy classes in Turkish secondary school education [Unpublished doctoral dissertation, Erciyes University, Institute of Social Sciences].

6. Tüzel, S. (2012). Media literacy education in primary school second grade Turkish lessons: An action research [Unpublished doctoral dissertation, Çanakkale Onsekiz Mart University, Institute of Education Sciences].

7. Ülker, M. (2012). Evaluation of curriculum and concistency of teachers guide book for the media literacy lesson [Unpublished doctoral dissertation, Gazi University, Institute of Education Sciences].

8. Inan, T. (2013). Media, parent-student relationships in the context of media literacy: Examining attitudes and behaviors of middle school students and their parents in relation to the use of television and internet [Unpublished doctoral dissertation, Dumlupınar University, Institute of Education Sciences].

9. Tanrıkulu, F. (2014). Enriched with children journal in the context of media literacy effectiveness of Turkish course: An action research [Unpublished doctoral dissertation, Çanakkale Onsekiz Mart University, Institute of Education Sciences].

10. Görmez, E. (2014). Media literacy levels of secondary school students [Unpublished doctoral dissertation, Atatürk University, Institute of Education Sciences].

11. Tan, O. (2015). Media literacy education: A sample research with respect to student, teacher and family [Unpublished doctoral dissertation, Akdeniz University, Institute of Social Sciences].

12. Aydoğdu, A. G. (2015). A study on new media literacy and new media consciousness for creating critical awareness [Unpublished doctoral dissertation, Gazi University, Institute of Social Sciences].

13. Koç, E. (2016). An application for media literacy education in Turkey [Unpublished doctoral dissertation, Maltepe University, Institute of Social Sciences].

14. Okuroğlu, M. S. (2016). The theory of critical media literacy: A field research in the scale of Eskişsehir high schools [Unpublished doctoral dissertation, Anadolu University, Institute of Social Sciences].

15. Kaplan, K. (2017). The competencies that the teachers of media literacy course should have during the integration process of media literacy and Turkish language teaching [Unpublished doctoral dissertation, Gazi University, Institute of Education Sciences]. 
16. Karataş, A. (2017). Determining teacher candidates' media literacy levels and a media literacy training programme for faculties of education [Unpublished doctoral dissertation, Gazi University, Institute of Education Sciences].

17. Alıcl, Ş. (2018). Investigating the impact of professional development on Turkish early childhood teachers' professional growth about education for sustainable development through critical media literacy [Unpublished doctoral dissertation, Middle East Technical University, Institute of Social Sciences].

18. Erdem, C. (2018). Designing a media literacy curriculum for preservice teachers [Unpublished doctoral dissertation, Anadolu University, Institute of Education Sciences].

19. Dolanbay, H. (2018). Media literacy education model for social studies pre-service teachers [Unpublished doctoral dissertation, Marmara University, Institute of Education Sciences].

20. Özel, A. (2018). Examining the perceptions of the preservice social studies teachers about media literacy [Unpublished doctoral dissertation, Dumlupınar University, Institute of Education Sciences].

21. Ulusoy, A. (2018). Digital media literacy and requirements, a study on innovative practices [Unpublished doctoral dissertation, Erciyes University, Institute of Social Sciences].

22. Aydemir, S. (2019). The effects of gender equality awareness media literacy training on the attitudes of prospective teachers about gender equality [Unpublished doctoral dissertation, Gazi University, Institute of Education Sciences].

23. Uyar, M. (2020). Children's internet use in the context of digital divide and media literacy: The case of Ankara [Unpublished doctoral dissertation, Gazi University, Institute of Social Sciences].

\section{Unpublished master's thesis}

1. Kartal, O. Y. (2007). The effect of media literacy on perception of television serials' messages for high school 10th grade students [Unpublished master's thesis, Çanakkale Onsekiz Mart University, Institute of Social Sciences].

2. Çetinkaya, S. (2008). The importance of media literacy in the awareness-raising process for media users [Unpublished master's thesis, Ankara University, Institute of Social Sciences].

3. Seylan, S. (2008). The deficiencies in media literacy course applications in the world [Unpublished master's thesis, İstanbul Kültür University, Institute of Social Sciences].

4. Apak, Ö. (2008). Examination of Turkey, Finland and Ireland primary school curriculum in terms of media literacy education [Unpublished master's thesis, Kocaeli University, Institute of Social Sciences].

5. Aslan, H. (2009). A study of media literacy in accordance with visual culture and art education [Unpublished master's thesis, Ondokuz Mayıs University, Institute of Social Sciences].

6. Ankaralıgil, S. Y. (2009). A research on media literacy and critical thinking of 6th and 7th classes' students in elementary school [Unpublished master's thesis, İstanbul University, Institute of Social Sciences].

7. Sadrıu, S. (2009). Media literacy elective courses field elementary students' second stage course to end outcomes 'pilot study' towards a [Unpublished master's thesis, İstanbul University, Institute of Social Sciences].

8. Keleş, S. (2009). Teachers' opinions about the curriculum of the media literacy in primary education [Unpublished master's thesis, Abant Izzet Baysal University, Institute of Social Sciences].

9. Bacaksız, T. (2010). Newspaper and journal usage in media literacy lesson: Determining the effects of the media literacy lesson on students reading habits of newspaper and journal, the case of Izmir [Unpublished master's thesis, Gazi University, Institute of Social Sciences].

10. İnan, T. (2010). Examining media literacy level of teacher candidates and their perspectives on media literacy [Unpublished master's thesis, Dumlupınar University, Institute of Social Sciences].

11. Bakan, U. (2010). The evaluation of the effect of critical thinking skills over primary education media literacy courses [Unpublished master's thesis, Atatürk University, Institute of Social Sciences]. 
12. Bütün, E. (2010). Teacher, studen and parents' view on media literacy course (Sample of Samsun city) [Unpublished master's thesis, Ondokuz Mayıs University, Institute of Social Sciences].

13. Aktı, S. (2011). Determining the relationship between media literacy and social skill levels of the eighth grade primary school students [Unpublished master's thesis, Firat University, Institute of Social Sciences].

14. Güner, F. (2011). The effect of media literacy to the perceptions of secondary school students television series messages [Unpublished master's thesis, Çanakkale Onsekiz Mart University, Institute of Social Sciences].

15. Yıldız, V. A. (2011). Media as a social learning tooland a critical view of media literacy from the perspective of moral development theories [Unpublished master's thesis, Atatürk University, Institute of Education Sciences].

16. Çelik, T. (2011). Affects of media literacy lesson over the social sciences teacher candidates developing multicultural attitudes [Unpublished master's thesis, Pamukkale University, Institute of Social Sciences].

17. Koçak, B. (2011). The perception of media literacy course of the primary students in seventh and eighth grade (Sample from Erzurum Province) [Unpublished master's thesis, Atatürk University, Institute of Education Sciences].

18. Yördem, A. (2012). Pre-service teachers perceptions of media literacy in the department of English language teaching in Turkey [Unpublished master's thesis, Çanakkale Onsekiz Mart University, Institute of Education Sciences].

19. Şahin, M. (2012). The differentiation of media consumption patterns of primary school student, who are taking and not taking media literacy course [Unpublished master's thesis, Marmara University, Institute of Social Sciences].

20. Sur, E. (2012). The opinious of secondary school teachers ans students in media literacy [Unpublished master's thesis, Niğde University, Institute of Education Sciences].

21. Avcl, i. B. (2012). Students course field view of media literacy for the media: Example Kayseri [Unpublished master's thesis, Selçuk University, Institute of Social Sciences].

22. Söylemez, Y. S. (2012). Media literacy education in Asia and Oceania: Comparison of Turkey and New Zealand [Unpublished master's thesis, Kocaeli University, Institute of Social Sciences].

23. Semiz, L. (2013). Media literacy competency of secondary students and the problems faced by teachers who conduct media literacy course [Unpublished master's thesis, Recep Tayyip Erdoğan University, Institute of Social Sciences].

24. Keleş, M. (2013). Study of media literacy course format in the context of critical pedagogy [Unpublished master's thesis, Atatürk University, Institute of Social Sciences].

25. Tuğrul, H. (2013). Media literacy as a tool for developing culture of democracy: The case of Turkey [Unpublished master's thesis, Gazi University, Institute of Social Sciences].

26. Sevim, F. (2013). Media literacy, gender and representation of women in the media [Unpublished master's thesis, İstanbul Commerce University, Institute of Social Sciences].

27. Çinelioğlu, G. (2013). The social sciences teacheres' attitudes towards media literacy lesson [Unpublished master's thesis, Balıkesir University, Institute of Social Sciences].

28. Aydoğdu, E. (2014). An analysis of the effects of the media literacies course on the conscious reading of the media passages [Unpublished master's thesis, Gazi University, Institute of Social Sciences].

29. Özay, C. (2014). Primary student's opinion interpretation of media literacy [Unpublished master's thesis, Marmara University, Institute of Education Sciences].

30. Sivritepe, S. (2014). Student's viewpoint to media litracy lesson: The case of Konya province [Unpublished master's thesis, Selçuk University, Institute of Social Sciences].

31. Cangin, S. Ş. (2014). Elementary students media literacy course perspectives (Ankara - Keçiören sample) [Unpublished master's thesis, Atatürk University, Institute of Social Sciences]. 
32. Naza, C. (2014). The attitudes of the secondary school students towards media literacy course [Unpublished master's thesis, Muğla Sıtkı Koçman University, Institute of Education Sciences].

33. Özdemir, K. (2015). Media literacy and teaching material in Turkey analysis of 2014 year media literacy material [Unpublished master's thesis, Anadolu University, Institute of Social Sciences].

34. Baş, G. (2015). Critical social media literacy in the context of new media image and body image presentation [Unpublished master's thesis, Ege University, Institute of Social Sciences].

35. Barut, E. (2015). New media literacy, communication skills and democratic tendency: An application of structural equation modeling [Unpublished master's thesis, Süleyman Demirel University, Institute of Education Sciences].

36. Solmaz, T. (2015). Media literacy in the context of new communication technologies [Unpublished master's thesis, Atatürk University, Institute of Social Sciences].

37. Işkın, P. (2015). A new media literacy programme based on teachers' opinions [Unpublished master's thesis, Ondokuz Mayıs University, Institute of Education Sciences].

38. Sayın, H. (2015). The place of media literacy skills in secondary school Turkish lesson curriculum and evaluation of students' skills of producing media texts [Unpublished master's thesis, Erciyes University, Institute of Education Sciences].

39. İslamoğlu, G. (2015). The use of new media platforms in developing the media literacy and a case study: Media Smart Web sites [Unpublished master's thesis, Kocaeli University, Institute of Social Sciences].

40. Göysarı, M. (2016). A comperative look at media literacy education in Turkey focusing on the shift to a more critical approach and new media updates in the curriculum [Unpublished master's thesis, Kadir Has University, Institute of Social Sciences].

41. Oflaz, T. (2016). Evaluation of students' perspectives on media within the scope of media literacy class: Case of Denizli province [Unpublished master's thesis, Yaşar University, Institute of Social Sciences].

42. Ardıç, E. (2016). Comparative study of post-graduate studies on media literacy: Turkey, USA and Canadian example [Unpublished master's thesis, Abant Izzet Baysal University, Institute of Education Sciences].

43. Tatar, i. (2016). Exploring the relationship between teacher candidates' media literacy and online information seeking strategies [Unpublished master's thesis, Anadolu University, Institute of Education Sciences].

44. İçelli, M, Y. (2017). Contrïbution of medïa literacy teachỉng material to medỉa literacy competencies [Unpublished master's thesis, Ege University, Institute of Social Sciences]

45. Pala, C. (2017). Media literacy: Concepts and theories [Unpublished master's thesis, Atatürk University, Institute of Social Sciences].

46. Yıldırım, Ş. (2017). Skills and views of turkish and social studies teachers on media literacy education [Unpublished master's thesis, Yüzüncü Yıl University, Institute of Education Sciences].

47. Buluş, B. (2017). Adult new media literacy: the case of European Union and Turkey [Unpublished master's thesis, Hacettepe University, Institute of Social Sciences].

48. Banaz, E. (2017). The media literacy levels of secondary education students (Giresun city sample) [Unpublished master's thesis, Giresun University, Institute of Social Sciences].

49. Yıldız, A. (2017). Parents' media literacy competency: Ankara field research [Unpublished master's thesis, Gazi University, Institute of Social Sciences].

50. Dumlu, A. (2018). Media literacy in EU countries in the context of developing participatory citizenship awareness [Unpublished master's thesis, Akdeniz University, Institute of Social Sciences].

51. Ekşioğulları, M. (2018). Evaluation of media literacy education and practices in critical context with Canada, Germany and Norway with Turkey [Unpublished master's thesis, Kocaeli University, Institute of Social Sciences].

52. Sabancı, Y. S. (2018). Social media literacy: Facebook and Instagram examples [Unpublished master's thesis, Marmara University, Institute of Social Sciences]. 
53. Kutlu, M. (2018). Similar approaches in the scope of media literature course and setbacks in the implementation: Kayseri example [Unpublished master's thesis, Erciyes University, Institute of Social Sciences].

54. Barut, M. (2018). An empirical study on the social opportunity of media literacy (A comparative analysis between academicians and citizens in Elaziğ city) [Unpublished master's thesis, Fırat University, Institute of Social Sciences].

55. Najaflı, M. (2018). Investigation of the secondary school students in the context of the media literature in the TV monitoring habits: Azerbaijan principles [Unpublished master's thesis, Erciyes University, Institute of Social Sciences].

56. Tanrıkulu, S. (2019). Media literacy and a study on the contribution of media literacy course to students [Unpublished master's thesis, Selçuk University, Institute of Social Sciences].

57. Zaınab, S. (2019). Media literacy policy in Pakistan [Unpublished master's thesis, Hacettepe University, Institute of Social Sciences].

58. Edin, P. G. (2019). Media literacy and problems in Turkey in comparative with the European legislation [Unpublished master's thesis, Gazi University, Institute of Social Sciences].

59. Türkan, S. (2019). The attitudes of students taking media literacy course towards social media [Unpublished master's thesis, Atatürk University, Institute of Education Sciences].

60. Tanriverdi Yılmaz, B. (2019). A research regarding the necessity of social media literacy in Turkey [Unpublished master's thesis, Marmara University, Institute of Social Sciences].

61. Koçak, M. (2019). An investigation of preschool teachers' perception of media literacy: Case of Erzurum province [Unpublished master's thesis, Atatürk University, Institute of Social Sciences].

62. Yardım, A. (2019). Attitudes of secondary school students to media literacy (Adiyaman sample) [Unpublished master's thesis, Adıyaman University, Institute of Social Sciences].

63. Şen, I. E. (2019). The assessment of the attitude of the $Z$ generation on the use of social media in the context of social media literacy 'Eskişehir scale research' [Unpublished master's thesis, Anadolu University, Institute of Social Sciences].

64. Alımcl, F. (2019). A research on internet media literacy awareness of parents in Kayseri [Unpublished master's thesis, Erciyes University, Institute of Social Sciences].

65. Aksu, Y. (2019). Studying attitudes of student and opinions of teacher and teacher candidate regarding the media literacy lesson [Unpublished master's thesis, Giresun University, Institute of Social Sciences].

66. Coşan, C. (2019). Field work under the perspective of media literacy education for elementary school students between ages 11-13 [Unpublished master's thesis, Marmara University, Institute of Social Sciences].

67. Eshetu, J. M. (2019). Social media literacy in the context of cultural diversity: A comparative analysis [Unpublished master's thesis, Marmara University, Institute of Social Sciences].

68. Gündoğan, B. (2019). The relation between media literacy and 'fake news' awareness of adolescents in Turkey [Unpublished master's thesis, Galatasaray University, Institute of Social Sciences].

69. Alınca, S. (2019). In İzmir Bornova and Karşıyaka working in adult education centers teachers and master trainers media literacy levels [Unpublished master's thesis, Ege University, Institute of Education Sciences].

70. Hansu, E. (2019). An empirical study of secondary education youth in terms of new media literacy [Unpublished master's thesis, Üsküdar University, Institute of Social Sciences].

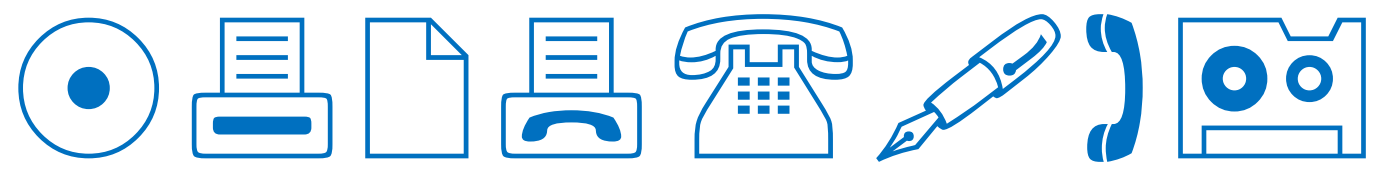

